\title{
Effects of Using Mnemonic Associations on Vocabulary Recall of Iranian EFL Learners over Time
}

\author{
Fatemeh Anjomafrouz ${ }^{1} \&$ Ghaffar Tajalli $^{1}$ \\ ${ }^{1}$ Department of English, Shiraz Branch, Islamic Azad University, Shiraz, Iran \\ Correspondence: Fatemeh Anjomafrouz, Beheshti Street, Khormouj, Bushehr, Iran. Tel: 98-772-622-4605. \\ E-mail: afrouz47@yahoo.com
}

Received: May 31, 2012 Accepted: June 23, 2012 Online Published: July 25, 2012

doi:10.5539/ijel.v2n4p101

URL: http://dx.doi.org/10.5539/ijel.v2n4p101

\begin{abstract}
Effects of using mnemonic associations on vocabulary recall of Iranian EFL learners were investigated in two separate experiments with adolescents and adults. In each experiment, the students were divided into two groups of experimental (mnemonic) and control (rote). Using a number of predesigned (the researcher-designed) associations as models, the students of the mnemonic groups were trained to generate mnemonic associations of their own for the new vocabulary words they had chosen to learn. Then, their use of the initial (previously student-designed) and the new self-designed associations was assessed by giving four recall tasks. The students of the rote groups, on the other hand, were instructed to learn the words through memorization and repetition. The data analyzed revealed that using mnemonic associations led to significantly better performance of the adult students when comparison was made with an external control group (rote group) and better performance of both adult and adolescent groups when comparison was made with an internal control group (when students used no association in mnemonic group). Furthermore, the higher performance of mnemonic groups who frequently reported using initial associations revealed that these had a significant role at vocabulary recall of students. Finally, mnemonic method significantly affected the vocabulary recall of adult students for both receptive and productive learning.
\end{abstract}

Keywords: mnemonic associations, initial association, internal control, recall tasks, dual coding theory

\section{Introduction}

Along with the idea of focusing on the good language learner, investigations have begun to isolate certain cognitive strategies to facilitate foreign language learning. Learning new vocabulary is a principal issue in learning of a foreign language. Such issue has led to a wide range of research and pedagogical interest. Despite this interest there has been considerable debate about the most effective way to develop students' FL vocabulary. One such issue concerns the effectiveness of a range of possible cognitive strategies (e.g. mnemonic associations) involved in vocabulary learning and empirical validation over time of the strategies actually mentioned. This study takes certain cognitive strategies - mnemonic associations mainly keyword strategy - to examine their effectiveness in a way that learners go through the process of self-selection to create a stronger link between their previous knowledge and newly-learned item. In this study we also examined the factor of age on vocabulary recall of participants. The reason for selecting different age groups results from our concerns that the use of adult subjects would produce biased results. Evidence shows that young children employ strategies that are simple and in a task-specific manner, while older children and adults make use of generalized strategies that are complex and sophisticated. For example, (Brown, Bransford, Ferrara, \& Campione, 1983; cited in Ellis, 1994) found that "rehearsal" for children consisted of rote repetition, while for adults it involved "active, systematic and elaborative procedures".

\subsection{Mnemonic Associations and Techniques}

Mnemonics as proposed originally by Simonides around 500 B.C.E. reemerged in the modern era as part of the general movement away from behaviorism and, more specifically, as a reaction against the verbal emphasis that continued to dominate the Ebbinghaus tradition, even in its mediational forms. According to Merriam Webster's dictionary (2004), the term mnemonic derives from the ancient Greek mnemonikos, from mnemon that means 
"mindful", This term is related to the term mnemosyne, the Greek goddess of memory and mother of the Muses by Zeus. Mnemonics are techniques or devices such as a rhyme or an image that serve to enhance the storage and the recall of information contained in memory (Solso, 1995; cited in Pillai, 2007). Children who are primarily visual or verbal learners are able to create a picture, word, rhyme, or sentence that is attached to an idea they already have. By using mnemonics, a learner can develop better ways to take in information so that it will be much easier to remember and retrieve (Mastropieri, Scruggs, \& Fulk, 1990; cited in Pillai, 2007). Mnemonic techniques include peg words (words associated with numbers used to remember lists of items), keywords (associating a similar-sounding word with a targeted word), acronyms (using the first letter of each word in a list to construct a word), acrostics that is creating a sentence where the first letter of each word is the targeted information, and loci (storing information you want to remember in carefully visualized locations) (Mastropieri et al., 1990; cited in Pillai, 2007; Cook, 2001)

According to Cohen and Aphek (1980) association is a mnemonic link to some element or elements that would help in recall of the word, including a link to meaning, sound, sound and meaning together, structure, context, mental image, letter(s) in the word, proper names, signs and so forth. The most common method in this area is mnemonic key word method developed by Atkinson and his collaborators (e.g. Atkinson, 1975; Atkinson \& Raugh, 1975; Raugh, Schupbach, \& Atkinson, 1977). The method, at the first stage, requires students to associate the spoken foreign word to a native word (the keyword) that sounds approximately like some part of the foreign word. At the second stage, it requires students to form a mental image of the keyword "interacting" with the English translation (Atkinson \& Raugh, 1975). As an example, consider the English word "espionage", meaning "jasoosi kærdæn" in Persian. Its pronunciation is like "esfenaj" in Persian. Using "esfenaj" as a keyword with the meaning of "spinach" in English, one could imagine a spy man with some dark green spinach on his face spying behind a tree. Unfortunately no research has been found using list of associations as Cohen and Aphek utilized in their work (1980). List of associations include those elements in the mnemonic devices before categorizing them into various methods and techniques such as keyword and peg word methods. The important issue to mention is that other than some elements, it is difficult to distinguish into what methods these element are to be categorized.

Theoretical explanations of the benefits of the keyword method point toward an important role of imagery according to the dual-coding theory of Paivio and colleagues (e.g. Paivio, 1971; 1986; 2006). Advocates of the dual-coding of theory maintain that two different but interconnected symbolic processing systems exist for encoding information - one verbal and other nonverbal. They propose that information is encoded in verbal, nonverbal, or both systems, depending on the task and concreteness or abstractness of the words read. Abstract words are more likely to activate verbal coding and concrete words are more likely to activate either nonverbal coding or a combination of both verbal and nonverbal systems. Therefore, the keyword method enhances learning and recall because the method uses both the verbal system and the image system in human memory. During learning, both verbal and image code are encoded in memory Assuming that these codes have additive effects, retrieval of the FL word is facilitated because there are two memory codes for the learning event, either of which can support recall (Flippo \& caverly, 2000; Kroll \& Groot, 2005).

\subsection{Strategy Training}

"Strategy training" is defined as intervention focusing on strategies to be used by language learners to develop proficiency or to improve in a particular task (Grenfell \& Harris, 1999). Strategy-training in a sense assumes that the strategies are teachable (Cook, 2001). That is along with the idea that teaching learners how to learn is crucial. Wenden (1985; cited in Brown, 2000) was among the first to assert that learner strategies are the key to learner autonomy, and that one of the most important goals of language teaching should be the facilitation of that autonomy. Regarding the significance of training strategies Oxford (1990) stated that language learning strategies encourage greater overall self-direction for learners. Self-directed learners are independent learners who are capable of assuming responsibility for their own learning and gradually gaining confidence, involvement and proficiency Thus, students need training in learning strategies they need most. In many investigations, attempts to teach students to use learning strategies (called strategy training or learner training) have produced good results (Thompson \& Rubin, 1993; cited in Oxford, 1994). However, not all L2 strategy training studies have been successful or conclusive. Some training has been effective in various skill areas but not in others, even within the same study. Teachers can benefit from an understanding of what makes learners successful, and establish in the classroom a milieu for the realization of successful strategies. Teachers can not always expect instant success in that effort since students often bring with them certain perceived notions of what "ought" to go on in the classroom (Bialystok 1985; cited in Brown, 2000). 


\subsection{Empirical Studies on the Effectiveness of Using Mnemonic-Based Methods}

A series of studies have investigated the effects of generating associative mnemonic links to help learn in recall of the words. Regarding the efficacy of using mnemonic associations, Carlson (1976; cited in Shapiro \& Waters, 2005) found significantly better recall when a group trained on the method of loci was compared to a control group. In another study the results from the peg method for recall of French vocabulary were reported to be quite successful (Paivio \& Desrochers, 1979; cited in Cohen \& Aphek, 1980). Cohen and Aphek (1980) empirically investigated whether the students made associations to help them remember the words through recall tasks, and if so, what words and how successful were these associations over time. The results revealed that there was a generally high success rate across all four tasks for recall of words that were learned through associations. Another study instructed students of German to associate three colors with grammatical gender to aid retrieval of article-noun lexical units and their meanings. Nyikos (1990; cited in Cohen \& Macaro, 2007) established that students remembered word meanings significantly better using color coding and color plus picture associations than in the picture-only condition.

A large number of studies have shown the facilitating or limitations of effects of the mnemonic-based methods on foreign vocabulary learning. The researchers of the present study could not provide sufficient studies including more than one mnemonic technique. However, among all mnemonic devices, the effect of keyword method has been very much attractive to researchers.

Some researchers have compared keyword method of learning new vocabulary with different methods or investigated it in combination with other methods (McDaniel \& Pressley, 1984; Mastropieri, Scruggs \& Fulk, 1990; Rodríguez \& Sadoski, 2000; Sajadi, 2006). For instance, in a study, Mastropieri, Scruggs and Fulk (1990) found that mnemonically trained students with learning disabilities outperformed control students on both abstract and concrete words, and on recall tests as well as on comprehension tests.

A number of studies have investigated the effectiveness of the keyword method for different age groups. The results of several studies have indicated that age is an important variable in the use of imagery-based recall methods and that such methods are useful for adult people (Atkinson \& Rough, 1975; Shapiro \& Waters, 2005); however, the modified keyword method does not always enhance the word recall of adult subjects (Hall, Wilson, \& Patterson, 1981; Pressley, 1987; Desrochers, Wieland, \& Cote, 1991). In line with that, the keyword method is effective among elementary school children (e.g., Wyra, Lawson, \& Hungi, 2007). In addition, adolescent students benefit from this method if subjects are treated individually (Pressley, Levin, Digdon, Bryant, Mcgivern, \& Ray, 1982) and if the quality of the keyword images is adequate (Beaton, Gruneberg, Hyde, Shufflebottom, \& Sykes, 2005). Moreover, the keyword method is less effective than rote method for both adults and adolescents (Campos \& Gonzalez, 2003).

It is interesting to note that Tomas and Wang (1996; cited in Gruneberg, 1998) conclude "There is a gap between the promise and practice of mnemonic learning that will be bridged only by demonstrations of naturalistic implementations that achieve positive long term outcomes". In spite of the fact that most retention studies have been conducted in laboratory-like setting, there is, however, some research conducted in natural setting (Gruneberg, 1998; Rodriguez \& Sadoski, 2000; Campos \& Gonzalez, 2003).

Perhaps the most important feature common to this research and that of Cohen and Aphek (1980) is to let students generate the associations of their own (the initial associations were the student-designed not the researcher-designed). According to Shapiro and Waters (2005), the reason why the keyword method may be effective is that it takes advantage of the strength of visual memory as well as requiring learners to expand a greater amount of cognitive effort. However, in comparison of a keyword-provided condition (Delaney, 1979) with a keyword-generated condition, the keyword-generated condition proved significantly more effective than keyword-provided condition, Shapiro and Waters (2005) found that the keyword's power does not arise from increased cognitive effort of generating keywords and interactions. Rather, it appears to stem from the use of visual imagery that ties a new word to its meaning.

Despite the fact that using mnemonic-based methods has frequently been reported to be useful in a number of studies, investigators have demonstrated some limitations of the mnemonic key word method. Gruneberg (1998) argues that the keyword method in general is inferior to rote learning in the longer-term retention of vocabulary. In another study, Campos and Gonzalez (2003) attribute ineffectiveness of keyword method to participants' 'lack of training. They investigated in four experiments the effectiveness of the mnemonic key word method using two groups of adults and adolescents. In all the experiments, the rote method was more effective than the keyword method for both adolescents and adults. 
This study introduces the use of mnemonic associations as a possible method for several reasons. Since the Grammar Translation Method (G.M.T.) and Audio Lingual Method (A.L.M.) of teaching English which are common in educational system in Iran and other Asian countries requires students to learn a large number of vocabularies for regular class tests and in preparation for university entrance examinations, mnemonics can improve their test scores. Another justification for conducting this study as Gray (1997) has stated, is that many students with disabilities and those at risk of educational failure have been consistently shown to have particular difficulties remembering academic content. Mnemonics can be used to increase learning and memory of these groups of students. Moreover, the purpose of this study is to determine the benefits of training students to make associations that best suit their needs, and look at the role of these associations in the retrieval of the new vocabulary words over time. In some previous studies (Mastropieri, Scruggs, \& Fulk, 1990; Rodríguez \& Sadoski, 2000), it was assumed that if a word that has been learned through association was recalled successfully, then the correct recall would be attributed to the original association. In this study, we want to find out to what extent correct recall is based on original association through the students' self-report on recall tasks. Therefore, the present study attempts to answer the following research questions:

1) Does training in word associations affect vocabulary recall?

2) Do initial associations affect the retrieval of vocabulary over time? Do students use new associations or stop using an association in recall, and if so, what happens to their recall of the word?

\section{Experiment with Adolescents}

In this experiment, we investigated the effectiveness of using mnemonic associations on vocabulary recall of students of guidance school.

\subsection{Method}

\subsubsection{Participants}

Seventy third-grade female students of guidance school from two intact language classes in Khormuj, Bushehr province, Iran took part in this study. One class with thirty-six students was selected as the experimental group (mnemonic). Another class with thirty-four students was selected as the control group (rote). At the beginning of the study all the students of the two classes participated in the study. However, in the analysis of data, only those who had got the scores of 14 to 20 out of 20 on the English final exams were chosen for homogeneity (50 students from the two schools), of whom 43 (23 as the mnemonic group and 20 as the rote group) were actually present in all sessions.

\subsubsection{Instruments}

The students in the mnemonic group received a list of associations elicited from Cohen and Aphek (1980) (Appendix A) along with the Persian version. The Persian version of the list of associations was constructed, consisting of basically the same associations as the English version, but modified to an Iranian setting. For instance, in one part of the constructed list of associations (context), the students were asked to link to the verses of the Holy Quran and hadithes. The next instrument was a reading passage taken from English book 1 for the first grade students of high school (Birjandi, Soheili, Noroozi, M., \& Mahmoodi, 2008). This included sufficient new vocabulary words. To provide the third instrument, the reading passage was manipulated through successive stages. Consequently, four recall tasks were provided. Each recall task consisted of 15 vocabulary words. Instruments for the rote group were the same as those for the mnemonic group, with the exception that the rote group did not receive any list of associations.

\subsubsection{Procedures for Data Collection}

The study was conducted longitudinally over a six-week period and during normal class time. The subjects were assigned to the mnemonic and rote groups. In the first week the mnemonic group was given a training session (40 minutes) on how to acquire foreign language vocabulary through the aid of associations. This was based on the vocabulary words of their English coursebook and a list of associations they received. They were also asked to use mnemonic associations for other words as an assignment for the next session.

In the second week, both groups received the reading passage. The passage was read and the students underlined the words they did not know. We provided the students with appropriate first language equivalents. The students were asked to select only 20 of these new words. The students in the association group were given 30 minutes to make associations for them indicating the type of associations they had generated. They constructed associations for all of these words. In order for the tasks to be valid with respect to the content of the recall tasks, we chose only 15 words that all students had similarly selected as opposed to Cohen and Aphek, (1980), where the recall 
tasks contained words some students had not chosen before. Furthermore, we selected only those words that at least one student had envisaged associations for them. Therefore, we selected the chosen words for which the students had generated associations. Similarly, the students in the rote method group were given 15 minutes to learn the said 20 words through memorization. They were instructed to repeat the English words and their translation several times.

A week later, the students in both groups were given an English word list, representing the words that they had chosen to learn, with the words in the same inflectional forms in a scrambled order. They translated each word into Persian. The mnemonic group wrote down the associations. After that, students received feedback concerning their performance on this task. Of course, this was for the purpose of increasing their motivation to participate actively in all sessions. They were not informed that the researcher would return a week later to administer a task, so that they would not try to reinforce their learning over that period.

In the fourth week, the students received the same passage which included all of the words that at least one student had got wrong on the first task. This passage was also read to them. The students translated the underlined words into Persian. The students in mnemonic group wrote the associations they had used to recall each word. In order to prevent practice effect on the test, students did not receive any feedback as to their performance neither on this task nor on the other two tasks.

During the fifth week, the students received the first passage again. The selected words were deleted and replaced by Persian equivalents. This time they provided English equivalents for the Persian words and the association group indicated the associations they had used.

In the sixth week, the students were again given the first word list. In this task, they were required to take the target words and write a sentence for each word. Since the students were not required to report any associations, this task contributed only to the total performance of students with respect to the comparison of two methods and did not play any role in statistical procedures and analyzing the data with respect to the second research question -the effect of initial associations. It must be added that, a t-test was used to examine the effects of using mnemonic associations with regard to the two research questions as presented in the following sections.

\subsection{Results and Discussion}

\subsubsection{Effect of Training in Word Associations on Vocabulary Recall}

The results presented in Table 1 indicate that training of adolescent group in mnemonic associations has not been effective, i.e. there was no significant difference between the performance of the two groups. The mnemonic group obtained the mean score of 43.38 as opposed to the rote group with the mean score of 40.30 . That the mnemonic group has no superiority over the rote group is congruent with the findings of Campos and Gonzalez (2003).

Table 1. Descriptive statistics and Independent Samples Test of vocabulary recall tasks for adolescent groups $(\mathrm{N}=43)$

\begin{tabular}{cccccccc}
\hline groups & $\mathrm{N}$ & Mean & $\mathrm{SD}$ & $\mathrm{MD}$ & $\mathrm{t}$ & $\operatorname{sig}(2$-tailed) & std. error difference \\
\hline Mnemonic & 23 & 43.38 & 14.23 & & & & \\
Rote & 20 & 40.30 & 20.15 & 3.07 & .58 & .562 & .58 \\
\hline
\end{tabular}

$\mathrm{P}<.05$

2.2.2 Effect of Initial Associations in the Retrieval of Vocabulary over Time

Taking mnemonic method into account, we continued our investigations on the role of initial associations in the retrieval of vocabulary over time. Thus, we needed to investigate different occasions existing in the mnemonic method. Since the students reported whether they had used an association and which one, it was possible to determine whether the average correct recall was related to the original association or a new one or even related to the cases where no association was used. It turned out that the students reported using the original association $-24.34 \%$ of the time, with a high average rate of recall $-85.28 \%$. They reported using a new association only $10.24 \%$ of the time with an average rate of recall of $64.44 \%$. They reported no longer using an association $16.42 \%$ of the time with an average rate of recall of $42.15 \%$. At last, for the $48.98 \%$ of the cases where no association had been used either at the time of learning or for recall, the average rate of correct recall was $30.73 \%$ (Table 2). 
Table 2. Retrieval strategies on the first three recall tasks (adolescents)

\begin{tabular}{llccccccc}
\hline & $\begin{array}{c}\text { Using } \\
\text { original } \\
\text { association }\end{array}$ & $\begin{array}{c}\% \\
\text { correct } \\
\text { recall }\end{array}$ & $\begin{array}{c}\text { Using new } \\
\text { association }\end{array}$ & $\begin{array}{c}\% \\
\text { Correct } \\
\text { recall }\end{array}$ & $\begin{array}{c}\text { No longer } \\
\text { using } \\
\text { association }\end{array}$ & $\begin{array}{c}\% \\
\text { correct } \\
\text { recall }\end{array}$ & $\begin{array}{c}\text { Using } \\
\text { no } \\
\text { association }\end{array}$ & $\begin{array}{c}\% \\
\text { correct } \\
\text { recall }\end{array}$ \\
\hline Mean & 24.36 & 85.28 & 10.24 & 64.44 & 16.42 & 42.15 & 48.98 & 30.73 \\
Std.D & 14.04 & 24.69 & 7.80 & 59.43 & 12.54 & 38.51 & 22.24 & 23.71 \\
N & 23 & 22 & 23 & 21 & 23 & 20 & 23 & 23 \\
\hline
\end{tabular}

Thus, we found that the performance of students when using original association - the second most utilized strategy - was significantly better than the occasions when they no longer used an association and used no association (Table 3). We also found that the students were almost successful to recall the words when they reported using new association. The average correct recall for the third occasion - no longer using association placed this strategy third on the list. Finally, we found that students most frequently reported using the cases where no association was used, but they revealed the least success in terms of the percentage of correct recall. These findings suggest that creation of associations over time is helpful in recall tasks. Along with Cohen and Aphek (1980) we also found that creating new associations may also be helpful in promoting correct recall.

It must be added that there was another way of investigating the actual effect of training without considering an external control group. In this experiment, students who had learned some words without using associations, served as a sort of internal control. In other words, their performance on the words that they linked to some associations (an average of 15.27 out of 45 words) was compared with their performance on words they did not report learning through association (an average of 6.95 words). The results revealed a significant difference in the performance of students (Table 3): they reported using associations with the average correct recall of $64.98 \%$, and for the occasions where no association had been used, the average correct recall was $21.52 \%$. Thus, training in word associations proved to be effective. Such results did not support the findings obtained by Cohen and Aphek (1980) in this respect.

Table 3. Descriptive statistics and Paired Samples Test of two occasions of adolescent mnemonic group

\begin{tabular}{cccccccccc}
\hline Occasions & $\mathrm{N}$ & Mean & $\mathrm{SD}$ & $\mathrm{MD}$ & Sd.D & $\begin{array}{c}\text { std. } \\
\text { error.D }\end{array}$ & $\mathrm{t}$ & $\mathrm{df}$ & $\begin{array}{c}\text { sig(2-tai } \\
\text { led) }\end{array}$ \\
\hline $\begin{array}{c}\text { Using } \\
\text { association }\end{array}$ & $\mathbf{2 3}$ & 64.98 & 19.91 & & & & & & \\
$\begin{array}{c}\text { Using no } \\
\text { association }\end{array}$ & $\mathbf{2 3}$ & 30.73 & 23.71 & 34.24 & 27.22 & 5.6 & 6.03 & 22 & $.000^{* *}$ \\
\hline
\end{tabular}

$\mathrm{P}<.05$

We can illustrate the nature of the data that were recorded and analyzed in order to produce numerical findings in two ways: 1) carrying out analyses by participants, and 2) performing the analyses by items. Knowing that $96 \%$ of the students had generated associations for at least one item, we can illustrate the nature of the data by selecting two sample students, one who generated associations only for two out of fifteen words and one who generated associations for thirteen words. The latter generated a variety of associations, although the emphasis was on sounds. Another way we looked at the data was to ask how individual words behaved across students. In terms of performing analysis by words, students had generated associations for 147 out of 345 words (42.60 in terms of percent of words) and the average level of correct recall across all four tasks was 44.27. Needless to say, some words lend themselves more readily to association than others. We compared two words - one word that stimulated a variety of associations and one that stimulated few. For example, the word tops "balaye", 18 students out of 23 (78.26 in terms of percent of students and with $51.81 \%$ correct response) found associations for it. The other two words, climb "bala ræftæn" and pick "ĉidæn", only 5 students (21.74 in terms of percent of students and with $11.96 \%$ and $36.96 \%$ correct response) reported generating associations for them. 
As we mentioned earlier, one reason that the keyword method may be effective is because it takes advantage of the visual imagery (Shapiro \& Waters, 2005). Furthermore, acquiring a word may be affected by the quality of the images. So, it is reasonable to posit that the word "tops" is an easily imaged word lending itself more to associations and is better remembered than the two other words, "climb" and "pick".

\section{Experiment with Adults}

\subsection{Method}

As for the adolescents, we set out to experiment with adult participants to see if age had any effects on vocabulary recall of participants over time.

\subsubsection{Participants}

One hundred and ten students studying different academic subjects from two pre-university English language classes at Azad University of Khormuj, Bushehr, from April to May 2009 participated in this experiment (30 females and 80 males). There were four pre-university English language classes from which two intact classes were selected. One class with a total of 60 students served as the mnemonic association group and another class with a total of 50 students served as the rote method group. The first received a list of associations and mnemonic training session but the second did not receive any of them. Those who received the scores of 12 to 23 out of 50 on Oxford Placement Test (Alen, 1985) were chosen for the purpose of homogeneity (60 students), of whom 50 students were actually present for all sessions.

\subsubsection{Instruments}

At the beginning stage of the research in mnemonic group, the Oxford Placement Test (Allen, 1985) was given to assess the homogeneity of the students. This test consisted of 50 items including grammar in multiple-choice format. Then we used the Persian version of the list of associations elicited from Cohen and Aphek (1980) (Appendix A). After that, the students received a reading passage taken from general English course book (Baradaran \& Khademzadeh, 2008) In order to examine the vocabulary recall of the students, the first passage was manipulated through successive stages. Consequently, four recall tasks were provided. The instruments for the rote group were the same as those for the mnemonic one, with the exception that the rote group did not receive any list of associations.

\subsubsection{Procedure for Collecting Data}

This part of the study was conducted longitudinally over a seven-week period and during normal class time. In the first week, for the purpose of homogeneity, Oxford Placement Test (Allen, 1985) was administered. The mnemonic group received treatment in a normal English class during normal class hours.

In the second week, the students of mnemonic group were given a training session (40 minutes) on how to learn second language vocabulary through the aid of associations. This was based on the new vocabulary words of their coursebook (Mirhassani \& Rahmani, 2005). They also received a Persian version of the list of associations elicited from Cohen and Aphek (1980).

A week later, the two groups received the reading passage. The passage was read and the students underlined the words they did not know. They were provided with appropriate first language equivalents. The students were asked to select only 20 of these new words. The students in the mnemonic group were given 30 minutes to make associations for them indicating the type of associations they had generated. In order to prepare four recall tasks, we chose only 15 words that all students had similarly selected to learn. Furthermore, we selected only those words that at least one student had found associations for them.

Similarly, the students in the rote method group were given 15 minutes to study the 20 words through repetition. They were instructed to repeat the English words and their translation several times.

During the remaining four weeks, they answered four recall tasks and reported the type of association used after each recall task. The rote method group did not receive any training or the list of associations. A t-test was used to examine the effects of using mnemonic associations on adult groups with regard to the research questions raised. 
Table 4. Procedures for collecting data for the two experiments

\begin{tabular}{lll}
\hline Session & Adolescent & Adult \\
\hline Session 1 first week & training session for mnemonic group & $\begin{array}{l}\text { Administering Oxford Placement } \\
\text { Test }\end{array}$ \\
Session 2 second week & $\begin{array}{l}\text { Presenting a reading passage for } \\
\text { mnemonic and rote groups }\end{array}$ & $\begin{array}{l}\text { Training session for mnemonic } \\
\text { group }\end{array}$ \\
Session 3 third week & $\begin{array}{l}\text { Administration of an English word } \\
\text { list task }\end{array}$ & $\begin{array}{l}\text { Presenting a reading passage for } \\
\text { mnemonic and rote groups }\end{array}$ \\
Session 4 fourth week & $\begin{array}{l}\text { Administration of an English- } \\
\text { word-in-context task }\end{array}$ & $\begin{array}{l}\text { Administration of an English } \\
\text { word list }\end{array}$ \\
Session 5 fifth week & Administration of a Persian- & $\begin{array}{l}\text { Administration of an English- } \\
\text { word-in-context task }\end{array}$ \\
Session 6 sixth week & Administration of an English word \\
list task (using a word in a sentence) & $\begin{array}{l}\text { Administration of a Persian- } \\
\text { word-in-context task }\end{array}$ \\
Session 7 seventh week & & $\begin{array}{l}\text { Administration of an English } \\
\text { word list task (using a word in a } \\
\text { sentence) }\end{array}$ \\
\hline
\end{tabular}

\subsection{Results and Discussion}

\subsubsection{Effect of Training in Word Associations on Vocabulary Recall}

The results gained from the adult groups revealed that the mnemonic group scored significantly higher than the rote group, with the mean score of 31.04 against 18.50 of the rote group and with the significant level of $p<.05$ as shown in Table 5 It appeared that after being trained in making associations, students of mnemonic group were relatively more successful in recalling foreign-language vocabulary learned through these associations than were the students of the rote group. The results were consistent with a growing body of literature claiming the effectiveness of mnemonic method in boosting the adult learners' vocabulary word recall (Atkinson \& Rough, 1975; McDaniel \& Pressley, 1984; Shapiro \& Waters, 2005)

Table 5. Descriptive statistics and independent samples test of vocabulary recall tasks for adult groups $(\mathrm{N}=50)$

\begin{tabular}{lcccccll}
\hline \multicolumn{1}{c}{ Groups } & $\mathrm{N}$ & Mean & $\mathrm{SD}$ & $\mathrm{MD}$ & $\mathrm{t}$ & $\operatorname{sig}(2$-tailed) & std. error difference \\
\hline Mnemonic & 27 & 31.04 & 14.58 & & & & \\
Rote & 23 & 18.50 & 14.00 & 12.54 & 3.06 & .008 & 4.09 \\
\hline
\end{tabular}

$\mathrm{P}<.05$

\subsubsection{Effect of Initial Associations in the Retrieval of Vocabulary over Time}

The results also showed that the students reported using the original association $-18.18 \%$ of the time, with a high average rate of recall $-93.22 \%$. They reported using a new association only $5.59 \%$ of the time with an average rate of recall of $73.40 \%$. They reported no longer using an association $12.83 \%$ of the time with an average rate of recall of $15.14 \%$. For the $63.37 \%$ of the cases where no association had been used either at the time of learning or for recall, the average rate of correct recall was $21.52 \%$ (Table 6). As with adolescent experiment these findings suggest that creation of associations over time is helpful in subsequent recall tasks.

Table 6. Retrieval strategies on the first three recall tasks (adults)

\begin{tabular}{llccccccc}
\hline & $\begin{array}{c}\text { Using } \\
\text { original } \\
\text { association }\end{array}$ & $\begin{array}{c}\% \\
\text { correct } \\
\text { recall }\end{array}$ & $\begin{array}{c}\text { Using new } \\
\text { association }\end{array}$ & $\begin{array}{c}\% \\
\text { Correct } \\
\text { recall }\end{array}$ & $\begin{array}{c}\text { No longer } \\
\text { using } \\
\text { association }\end{array}$ & $\begin{array}{c}\% \\
\text { correct } \\
\text { recall }\end{array}$ & $\begin{array}{c}\text { Using } \\
\text { no } \\
\text { association }\end{array}$ & $\begin{array}{c}\% \\
\text { correct } \\
\text { recall }\end{array}$ \\
\hline Mean & 18.18 & 93.22 & 5.59 & 73.40 & 12.83 & 15.14 & 63.37 & 21.52 \\
Std.D & 12.52 & 12.56 & 4.33 & 30.63 & 12.83 & 25.45 & 22.60 & 18.39 \\
N & 27 & 23 & 27 & 23 & 27 & 20 & 27 & 27 \\
\hline
\end{tabular}


In addition, in this experiment, the students' performance on the words that they linked to some associations (an average of 11.90 out of 45 words) was compared with their performance on words they did not report learning through association (an average of 6.98 words). The results revealed a significant difference in the performance of students: they reported using associations $36.79 \%$ of the time with the average correct recall of $91.00 \%$, and for the $63.37 \%$ of the occasions where no association had been used, the average correct recall was $21.52 \%$. Thus, training in word associations proved to be effective (Table 7).

Table 7. Descriptive statistics and paired samples test of two occasions of adult mnemonic group

\begin{tabular}{|c|c|c|c|c|c|c|c|c|c|}
\hline Occasions & $\mathrm{N}$ & Mean & & Sd.D & MD & $\begin{array}{c}\text { std. } \\
\text { error.D }\end{array}$ & $\mathrm{t}$ & $\mathrm{df}$ & $\begin{array}{l}\operatorname{sig}(2-\text { tai } \\
\text { led })\end{array}$ \\
\hline $\begin{array}{l}\text { Using } \\
\text { association }\end{array}$ & 26 & 91.00 & 11.90 & & & & & & \\
\hline $\begin{array}{l}\text { Using no } \\
\text { association }\end{array}$ & 26 & 21.58 & 18.75 & 21.87 & 69.40 & 4.29 & 16.17 & 25 & $000 * *$ \\
\hline
\end{tabular}

$\mathrm{P}<.05$

As with adolescent experiment, the nature of the data can be illustrated in two ways: 1) carrying out analyses by participants, and 2) performing the analyses by items. Considering that $89 \%$ of the students had generated associations for at least one item, we selected two sample students, one student who generated an association only for one out of fifteen words and one who generated associations for all fifteen words. The latter generated a variety of associations, but the emphasis was on sounds. As for the analysis by words, the students had generated associations for 127 out of 405 words (31.36 \% of words) and the average level of correct recall across all four tasks was 31.23 . We compared two words - one word that stimulated a variety of associations and one that stimulated only few. For instance, the word career "herfe or kar", 15 students out of 27 (55.56\% of students with $51.23 \%$ correct response) found associations for it. The second word, employer "karfærma", only 3 students (11.11\% of students with $39 \%$ correct response) reported generating associations for it. According to the above results, we can propose another reason for the possibility of a word lending itself to association. The words including the parts that directly link to the meaning lend themselves more readily to association. Actually, these words associate with their meanings in themselves. The first part of the word career, "car", resembles the word "kar" in Persian that has the same meaning as career.

\section{Conclusions, Pedagogical Implications and Suggestions}

Based upon the results yielded in the study several conclusions are drawn. The overall aim of the present study was to assess whether using mnemonic associations was effective in classroom setting and whether it was suitable for practical use by students as a learning strategy. The data analyzed revealed that using mnemonic associations led to significantly better performance of the adult students when comparison was made with respect to an external control group (rote group) and better performance of both adult and adolescent groups when comparison was made with respect to an internal control group (when students used no association in mnemonic group). Furthermore, the higher performance of mnemonic groups who frequently reported using initial associations revealed that initial associations had a significant role at vocabulary recall of students. According to these findings the mnemonic-based methods may turn out to be useful for different age groups.

As it was noted earlier, the most common method of associative mnemonic links is mnemonic keyword method coined by Atkinson (1975). It is used to make meaningful auditory and imagery links to remember a word. Since the keyword method is typically thought of as an imagery technique, one might expect that some kind of individual imagery ability and the quality of keyword image would be quite important for better performance of the students. Individual differences in visual imagery are predicted within dual coding theory in which people are seen to vary in their tendency and capacity to use imagery (Clark \& Paivio, 1991). Regarding the quality of keyword image, Pressly and Levin (1981) identified degree of keyword overlap (the degree to which the keyword overlaps phonemically with the foreign word to be recalled) as one factor influencing retention. Thus, good images are likely to have high degrees of phonemic overlap with the target words. Consider the English word "top" which is translated /balaye/ (Appendix B) in Persian. /tap/ as a link overlaps considerably with the English word. We admit that it may not be easy to find good associative mnemonic links for all words in a language. In sum, there are some words and some individuals for whom the keyword method will work less well than for others. It is obviously important to know for what specific items and learners the keyword method is best suited. 
Attempts at generating mnemonic associations may produce effects beyond the recall of new vocabulary words. In generating associations whether by the instructor or by the students themselves, there are opportunities for creative use of associative links-more specifically mental image and sound links - both in and outside of the classroom. For example, an instructor may choose to provide associative links that are designed to make students laugh and enjoy the class, while still enjoying the proven benefits of using mnemonic associations. There is considerable evidence (see. e.g. Gruneberg \& Jacobs, 1991; cited in Gruneberg, 1998) that users find the keyword method much more enjoyable and motivating than rote learning. In addition, as Shapiro and Waters (2005) have asserted, the method can also be turned into a game in which the entire class participates. For example, each student can be given one or more words and assigned the task of coming up with keywords and interactions to present to the class. In this way, class members enjoy themselves, get to know their classmates, and help each other with vocabulary. The exercise can be turned into a contest for the most outrageous or memorable images. Such games can be very motivating to students and they are pedagogically sound.

Though some positive findings were identified in this study to claim the effectiveness of using mnemonic associations on the vocabulary recall of Iranian EFL learners, some limitations of the present study must be noted before the results could be generalized. It is worth mentioning that at least some of the students in the mnemonic condition had not faithfully followed the appropriate directions for the mnemonic method. Likewise, students in the rote method had spontaneously used other strategies, including imagery. Furthermore, though in training session the students participated actively and voluntarily in generating associations for the words and found the method enjoyable, in the presentation session there were many students who refrained from generating associations for the chosen words existing in the reading passage. The possible reason for the students' unwillingness can be searched in the effort involved in memorizing words in this manner, considering the fact that it takes much time to generate associations even for a small number of words. The recommendation is that the instructor supplies associations for some words whenever requested by the students. As a whole, the results of the present study would be generalizable only to the third-grade students of guidance schools in Khormuj and students of Khormuj Azad University studying different academic majors, and learners of English as a foreign language.

Since it appears that investigation related to the effects of using mnemonic associations has attracted the attention of few researchers in Iran, to provide more evidence for the effectiveness of such methods in natural settings, further comprehensive research in this area is recommended. Further research is also suggested on the effects of some factors like the learners' beliefs and motivation about language learning on using mnemonic associations and the students' performance, the effects of using mnemonic associations on vocabulary recall with respect to the type of recall tasks and investigating the process of progress during four recall tasks, the effects of using mnemonic associations and of ability to image on English language vocabulary recall and the effect of the quality of keyword image on vocabulary recall.

\section{Acknowledgements}

The authors would like to acknowledge the cooperation of the students of guidance school and Islamic Azad university students who participated in the project.

\section{References}

Atkinson, R. C. (1975). Mnemotechnics in second-language learning. American Psychologist, 30, 821-828. http://dx.doi.org/10.1037/h0077029

Atkinson, R. C., \& Rough, M. R. (1975). An application of the mnemonic key word to the acquisition of a Russian vocabulary. Journal of Experimental Psychology, 104, 126-133.

Baradaran, A., \& Khademzadeh, M. M. (2008). General English through reading. Tehran, Zaban-e-Daneshjoo, 35-36.

Beaton, A. A., Gruneberg, M. M., Hyde, Ch., Shufflebottom, A., \& Sykes, R. (2005). Facilitation of receptive and productive foreign vocabulary learning using the keyword method. The role of image quality, 13, 458-471.

Bialystok, E. (1985). The compatibility of teaching and learning strategies. Applied linguistics, 6, 255-262. http://dx.doi.org/10.1093/applin/6.3.255

Birjandi, P., Soheili, A., Noroozi, M., \& Mahmoodi, Gh. (2008). English book 1. Iran course books publication, 24. 
Brown, A., Bransford, J., Ferrara, R., \& Campione, J. (1983). Learning remembering and understanding. In J. Flavell, \& E. Markman (Eds.), Carmichael's manual of child psychology (pp. 77-166). New York: Wiley.

Brown, H. D. (2000). Principles of language learning \& teaching (4th ed.). NY: Longman/Pearson Education.

Campos, A., \& Gonzalez, M. A. (2003). Limitations of the mnemonic-keyword method. Journal of Educational Psychology, 130(4), 399-413.

Carlson, R. F., Kincaid, J. P., Lance, S., \& Hodgson, T. (1976). Spontaneous use of mnemonics and grade point average. Journal of psychology, 92(1), 117-122. http://dx.doi.org/10.1080/00223980.1976.9921344

Clark, J. M., \& Paivio, A. (1991). Dual coding theory and education. Educational Psychology Review, 3(3), 149-210. http://dx.doi.org/10.1007/BF01320076

Cohen, A. D., \& Aphek, E. (1980). Retention of second-language vocabulary over time: Investigating the role of mnemonic associations. System, 8, 221-235. Pergamon Press. http://dx.doi.org/10.1016/0346-251X(80)90004-4

Cohen, A. D., \& Macaro, E. (2007). Language learner strategies. New York, NY: Oxford University Press.

Cook, V. (2001). Second language learning and language teaching (3th ed.). New York, NY: Oxford University Press.

Delaney, H. D. (1979). Individual differences and materials differences which may affect keyword method utility. (ED186441)

Desrochers, A., Wieland, L. D., \& Cote, M. (1991). Instructional effects in the use of the mnemonic keyword method for learning German nouns and their grammatical gender. Applied Cognitive Psychology, 5(1), 19-36. http://dx.doi.org/10.1002/acp.2350050103

Ellis, R. (1994). The study of second language acquisition. New York, NY: Oxford University Press.

Flippo, R. F., \& Caverly, D. C. (2000). Handbook of college reading and study strategy research (2nd ed.). Journal of College Reading and Learning. Retrieved from http://books.google.com/books?id

Gruneberg, M. M., \& Jacob, G. C. (1991). In defense of linkword. Language Learning Journal, 3, 25-29. http://dx.doi.org/10.1080/09571739185200091

Gruneberg, M. M. (1998). A commentary on criticism of the keyword method of learning foreign. Applied Cognitive, 12, 529-532. Retrieved from http://web.ebscohost.com/ehost/detail?sid=f884b09a

Hall, J. W., Wilson, K. P., \& Patterson, R. J. (1981). Mnemotechnics: Some limitations of the mnemonic keyword method for the study of foreign language vocabulary. Journal of Educational Psychology, 73(3), 345-357. http://dx.doi.org/10.1037/0022-0663.73.3.345

Kroll, J. F., \& DeGroot, A. M. B. (2005). Handbook of bilingualism. Oxford University Press.

Mastropieri, M. A., Scruggs, T. E., \& Fulk, B. M. (1990). Teaching abstract vocabulary with the keyword method: Effects on recall and comprehension. Journal of Learning Disabilities, 23(2), 92-96. http://dx.doi.org/10.1177/002221949002300203

McDaniel, M. A., \& Pressly, M. (1984). Putting the keyword method in context. Journal of Educational Psychology, 76(4), 598-609. http://dx.doi.org/10.1037/0022-0663.76.4.598

Mirhassani, A., \& Rahmani, N. (2005). Reading skillfully 1. Tehran: Zabankadeh Publication.

Nyicos, M. (1990). Sex-related differences in adult language learning: Socialization and memory factors. Modern Language Journal, 74(3), 273-287. http://dx.doi.org/10.1111/j.1540-4781.1990.tb01063.x

Oxford, R. (1990). Language learning strategies: What every teacher should know. Rowley, Mass: Newbury House.

Oxford, R. (1994). Language learning strategies: An Update. Retrieved from http://www.cal.org/resources/digest/oxford01.html

Paivio, A. (1971). Imagery and verbal processes. New York: Holt, Rinehart, and Winston.

Paivio, A. (1986). Mental representation: a dual coding approach. Oxford: Oxford University Press.

Paivio, A. (2006). Dual coding theory and education. Draft chapter for the conference on "Pathways to literacy achievement for high poverty children". The University of Michigan School of Education. Retrieved from http://www.csuchico.edu/ nschwartz/paivio.pdf 
Paivio, A., \& Desrochers, A. (1979). Effects of an imagery mnemonic on second language recall and comprehension. London, Ontario: Department of Psychology, University of Western Ontario.

Pillai, N. R. (2007). Using visual mnemonics to help students remember the spelling of irregular plural nouns. Prosiding Seminar Penyelidikan Pendidikan IPBA.

Pressley, M., \& Levin, J. R. (1981). The keyword method and recall of vocabulary words from definitions. Journal of Experimental Psychology: Human Learning and Memory, 7(1), 72-76. http://dx.doi.org/10.1037/0278-7393.7.1.72

Pressley, M., Levin, J. R., Digdon, N., Bryant, S. L., Mcgivern, J. E., \& Ray, K. (1982). Re-examining the "Limitations" of the Mnemonic Keyword Method. Wisconsin Center for Education Research, Working Paper No. 329. Retrieved from http://www.eric.ed.gov/ERICWebPortal/search /detailmini

Raugh, M. R., Schupbach, R. D., \& Atkinson, R. C. (1977). Teaching a large Russian vocabulary by the mnemonic keyword method. Instructional science, 6, 199-221. http://dx.doi.org/10.1007/BF00120656

Rodriguez, M., \& Sadoski, M. (2000). Effects of Rote, Context, Keyword, and Context/Keyword Methods on Retention of Vocabulary in EFL Classrooms. Language Learning, 50(3), 385-412. http://dx.doi.org/10.1111/0023-8333.00121

Sajadi, M. (2006). The effect of teaching vocabulary through keyword method on Iranian EFL learners. Vocabulary memorization and retrieval. MA Thesis in English teaching. Shiraz Islamic Azad University.

Shapiro, A. M., \& Waters, D. L. (2005). An investigation of the cognitive processes the keyword method of foreign vocabulary learning. Language Teaching Research, 9(2), 129-146. http://dx.doi.org/10.1191/1362168805lr151oa

Solso, R. L. (1995). Cognitive psychology. Allyn and Bacon: Boston.

Thomas, M. H., \& Wang, A. Y. (1996). Learning by the keyword mnemonic: Looking for long term effects. Journal of Experimental Psychology: Applied, 2, 330-342. http://dx.doi.org/10.1037/1076-898X.2.4.330

Thompson, I., \& Rubin, J. (1993). Improving listening comprehension in Russian. Washington, DC: Department of Education, International Research and Studies Program.

Wenden, A. L. (1985). Learners strategies. TESOL Newsletter, 19(5), 1-7.

Wyra, M., Lawson, M. J., \& Hungi, N. (2007). The mnemonic keyword method: The effects of bidirectional retrieval training and of ability to image on foreign language vocabulary recall. Learning and Instruction, 17, 360-371. Retrieved from http://dx.doi.org/10.1016/j.learninstruc.2007.02.008

\section{Appendixes}

Appendix A: List of associations (Note 1) (Modified version of Cohen and Aphek (1980))

The following is a list of suggested associations for learning new vocabulary words. It is possible that you will combine two or more associational types for a given word. Please familiarize yourself with this list and bring it with you to the next session.

- Meaning (Examples will be collected from participants)

- Sound L1 - parsi- parsimony - /særfeju/ (irani-ha særfeju hæstænd)

L0 (Dashti accennt) - seil kærdæni - salient- /ĉesmgir/

L2 - minous - ominous - menace - both words mean /tæhdid konænde/

- Structure L2 - alacrity - /ĉa boki//

- Topic groups - e.g. a) objects - clothing, food.

b) concepts - anger, beauty, request,

c) word class - adverbs

- Context - e.g. Quran verses, hadithes, textbook, poem, song, music, idiom, film.

- Mental image - e.g. action, picture, photo, sketch, painting, gesture, color.

1. Picture: espionage /jasusi kærdæn/ (imagine a spy man with some dark spinach (2esfenaj in Persian) on his face spying behind a tree) 
2. gesture: siege/2ehate daŝtæn/when learning this word, we keep our hand open in a way that it is surrounding something. When recalling the word the gesture acts as an association to recall.

- Personal experience or situation. (Examples will be collected from participants)

- Shape of word (Examples will be collected from participants)

- Number of letters in word (Examples will be collected from participants)

- By letters - e.g detain /toqif kærdæn/ " $\mathrm{t}$ " exists in both words

- Stress (Examples will be collected from participants)

- Tone of voice (Examples will be collected from participants)

- Rhythm - e.g chagrin - /ĝææmgin - ĝæm/

- Touch (Examples will be collected from participants)

- Taste - e.g. lothe-/tænæffor daŝtæn/-/mæn ?æz loz motenæfferæm/ (loz is the name of a fruit)

- Smell (Examples will be collected from participants)

- Certain person - e.g. bizarre - /2æjib/ - (Bizaru is the name of a woman in our town.) "Bizaru is

$$
\text { a bizarre name" - /bizaru 2esme 2æjibi २æst/ }
$$

-Proper name - e.g. butcher's /ĝæssabi/ - (Bushehr is the name of a province in Iran) - "We went

$$
\text { to a butcher's in Bushehr" /dær Busheher be qæssabi ræftim/ }
$$

- Sign (Examples will be collected from participants)

KEY: $\mathrm{L} 1=$ native language, $\mathrm{L} 2=$ target language, $\mathrm{L} 0=$ other language or accent

Appendix B: Some types of associations designed (Note 2)

\section{a) Meaning (of the part)}

view /didæn/ - interview - /mosahebe/ "At an interview, two people look at each other"

\section{b) Sound}

1) Target language to native language

must-/bayæd/ $\rightarrow$ /mast/ "yogurt" - "He must eat yogurt" /2u bayæd mast bekhoræd/

grow -/roŝd kærdæn/ $\rightarrow$ /giah/ "plant" - "plant grows"/giah roŝd mikonæd/

prefer - /tærjih dadæm/ $\rightarrow$ /porefer/ "curly" - "I prefer curly hair to straight hair"

/mæn muhaye por fer ra be muhaye saf tærjih midæhæm/

2) Target language to target language

Raise /pærværeŝ dadæn/ $\rightarrow$ rice /berenj/ - "We raise rice" /ma berenj pærværeŝ midæhim/

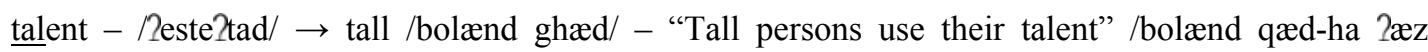

?este?tad-eŝan ?estefade mikonænd/

capable - /tævana/ $\rightarrow$ can /tævanestæn/

3) Target language to local accent

grow - /roŝd kærdæn/ $\rightarrow$ /got (in Dashti accent)/ "big” - "to get bigger” /bozorgtær ŝodæn/

tops - /balaye/ $\rightarrow /$ tap/ - "name of something at the top of date tree in Dashti"

pick - /ĉidæn/ $\rightarrow$ /pik/ "empty" - "I picked the empty walnuts" /mæn gerduhaye puk ra ĉidæm/

4) Onomatopoeic in target language

drop - /2oftadæn/ $\rightarrow$ tolop - "the sound of dropping a piece of stone into the water"

5) Target language to native language to target language

career - /kar ya herfe/ $\rightarrow$ /kar/ "career"

c) Structure capable - /tævana/ $\rightarrow$ able

d) Topic group eventually $\rightarrow \underline{\mathrm{l}}-$ finally /særænjam/ "word class - adverbs" 


\section{c) Context}

resume /sabeqeye ŝogli-tæhsili/ "they had seen the word in job application forms"

clever /bahuŝs - "name of a clever girl in a film"

fun /xændedar/ "they had heard the word in a song"

\section{e) Mental image}

1) Picture: tops - /balaye/ $\rightarrow /$ tap/ - "imagine some tap at the top of date tree"

field /keŝtzar/ $\rightarrow$ /fil/ "elephant"- "imagine an elephant in a field"

2) Gesture: drop - /2oftadæn/ $\rightarrow$ when translating the word, I had unconsciously moved my hand in a way as if I was dropping something down. When learning and recalling the word by students the gesture acted as an association.

f) Number of letters in word pick/ĉidæn/ جيدن (four letters)

\section{g) By letters}

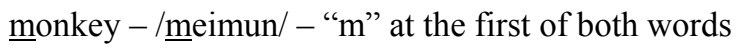

ripe - /reside/ - "r" at the first of both words

\section{g) Tone of voice}

resume /sabeqeye ŝogli-tæhsili/ $\rightarrow$ They recalled it, since I pronounced it in a special way

h) Rhythm necessary - /lazem - o - zæruri/ - "sary” is pronounced like /zæruri/

\section{i) Proper name}

prosperous - /movæfæq/ $\rightarrow$ /Perspolis/ "name of a team in Iran" $\rightarrow$ "Perspolis team is prosperous" /time perspolis movæfæq ?æst/

interview - /mosahebe/ $\rightarrow$ /Inter Milan/ "name of a team in Italia" $\rightarrow$ "interview with Inter Milan coach"

Capable - /tævana/ $\rightarrow$ "name of a capable person in a film"

\section{j) Using target language in native language}

clever /bahuŝs - "My aunt tell me you are clever" $\rightarrow$ /xale-æm miguyæd to keleveri/

climb /bala ræftæn/ - "To pick coconuts, you should climb the tree" $\rightarrow$ /bæraye cidæne coconut bayæd climb the tree bekoni/

fun /xændedar/ - "What a funny word you said!" $\rightarrow$ /ĉe hærfe funi zædi!/

k) Emotion fun /xændedar/ - They like the meaning of the word "fun".

L) Taste coconut /nargil / - They learned it, because they liked the taste of coconut.

\section{Notes}

Note 1. The list of associations can be modified through eliciting examples from the students.

Note 2. Some of the examples could actually be interpreted as combinations of two or more categories. 